\title{
The Influence of Rois as an Agent of Religious Rituals
}

\author{
Siti Afifah Adawiyah \\ Department of Islamic Education, \\ Faculty of Islamic Studies, Master of \\ Islamic Studies, Faculty of Islamic \\ Studies \\ Islamic University of Indonesia \\ Yogyakarta, Indonesia \\ afiadawiyah@uii.ac.id
}

\author{
Junanah \\ Department of Islamic Education, \\ Faculty of Islamic Studies \\ Islamic University of Indonesia \\ Yogyakarta, Indonesia \\ junanah@uii.ac.id
}

\author{
Supriyanto Pasir \\ Department of Islamic Education, \\ Faculty of Islamic Studies \\ Islamic University of Indonesia \\ Yogyakarta, Indonesia \\ supriyanto_pasir@uii.ac.id
}

\begin{abstract}
The background of this research is the public perception of the role of Rois is only a prayer reader in religious rituals. Preliminary observations show that the community views the role of the rois as limited to the reader of prayer. This study aims to describe the role of Rois in building an Islamic community in Maguwoharjo Village. This research is a qualitative study using the sociological approach of religion. Data collection is done by observation, in-depth interviews and documentation. The results of the study show that the rois task is taking care of the mortuary process, leading the prayer, and guiding the community back to Islamic teachings, while the challenges faced by rois are to be ready 24 hours and the differences understanding among the community. from this research, it is found that the requirements for becoming a rois in the village are broad religious insights, practicing the teachings of Islam until it can be a representative of a moeslem, reading the Qur'an fluently, elderly, approved by the community, and willing to carry out the duties as leader on the community.
\end{abstract}

\section{Keywords-Rois, Religious Rituals, Islamic Community}

\section{INTRODUCTION}

Religion always plays its function as the spirit of life. The belief that God is together with humans so that individuals are optimistic to live life in the world with all the challenges becomes one of the characteristics of the spirit of life.[1] In addition, the roles of religion for some people are as a source of value, a source of identity and source of rules. Ibn Khaldun (1406) as a Muslim scientist describes that religion is a driving factor for someone to do good deeds or actions. He also explained that religion is crucial for the formation of one's character and personality because religion is a source of moral and ethical legitimacy.[2] To be conclude, religion acts as an individual benchmark to distinguish between good and bad things in action. From the thought of Ibn Khaldun it is understandable that religion is a positive thing for an individual and even a group, therefore religious education is an important consideration for the development of one's personality.

As previously stated, religious education is important so that not only students in schools or madrasas learn religious education, but the community also needs to learn it, so that the school or madrasah with the community becomes aligned, so that what students learn in school is not different from reality in the community. The reality that exists in social life is that in every village led by a religious leader or better known as rois or kaum. In general, this Rois task is to foster the community in religious matters.[3] This means that Rois directly fosters religious education in the community. It is understandable that the community gets religious education from Rois.

Rois or Kaum is a term for a man in a community, especially in Java, while in Sumatra it is called Fāqih or sholeh. Hierarchically, Rois gets special attention from either the KUA (Religious Affairs Office) or the local village office. In collaboration with the KUA and local village offices, namely the Head of the Public Welfare Section in the area, a rois builds on the religious matters of the community. It can be said that Rois is a party whom helps the KUA apparatus and local village offices to be more easily connected with the community, especially matters relating to the religious sector.

In order to implement PMA No.2 of 1990, specifically article 4, and Joint Declaration of the Minister of Home Affairs and Minister of Religion of the Republic of Indonesia No.3 of 1947, each rois has a treatise intended to assist his duty as rois to provide services in the field of social worship to Muslims in the community.[4] This treatise serves as a guideline for Rois to carry out their duties because they contain rules and prayers for carrying out social worship. Intended social services include helping to take care of the deceased, ranging from bathing, wrapping the corpse, praying, leaving to burial and marriage, aqiqah seven-month program, laying the first stone for the construction of a house or building, good fortune having a new home or success in business or academic fields, Islamic holidays, Friday moslem sermons and Islamizing those who wanted to become a moslem.

From the description above, it can be assume that the public perception of the existence of the rois does not reach religious coaching. In the view of the wider community, Rois has the main task as a prayer reader only, leading religious rituals in several community activities. This can be happened because people in Yogyakarta are still hold Javanese customs such as selametan, kenduri, seripah and so on. In addition, the public perception that Rois, also known as the Mbah Kaum, is identical to the role of an old prayer reader.[5] It can be conclude that Rois's task only limited to leading prayers only in religious rituals in the community activities.

This research conducted for exploring how far the role of Rois in building an Islamic society. The area that examined was Maguwoharjo, where the people are heterogeneous communities. Maguwoharjo village has a total of 59 rois who 
play a role in teaching Islamic teachings in the community. The population is mostly Muslim and others are Catholic and Christian, because there are several churches in the area. By taking a sample of the people of Maguwoharjo who live on the countryside with heterogeneous communities, the role of rois certainly has a big role in instilling Islamic values in the Maguwoharjo Village community

\section{THEORETICAL FRAMEWORK}

Before discussing the role of Rois, it is necessary to elaborate on the notion of Rois to limit the intentions of the study. In terms of language, basically the word "rois" comes from Arabic, namely raasa-yarasu-ra'san-wariaasatan which means to head, preside, lead.[6] In the Arabic Indonesian dictionary, the word rois as fa'il means leader or clan leader.[7] Whereas in the Indonesia Dictionary, it is written rais for rois, which means leaders of the community, head, chairman, leader; president.[8] Viewed from a different perspective, the head can be interpreted as an organ of the body, the center of the activity of the human body. Inside the head there is a brain that is the center of human movement. Conclusions can be drawn, in the language of the word rois is a person who is able to become a driver or can be called a leader.

To be a leader there are several ways, sometimes without any effort an individual can become a leader. This is certainly caused or motivated by several things. The following are things that cause a person to become a leader: (1) Tradition / inheritance: someone becomes a leader, because of inheritance, such as the king or queen of England and the Netherlands. Other examples such as Sri Sultan Hamengkubuwono at the Sultan Palace, (2) Personal strength, both for physical reasons and because of his skills, (3) Appointment of superiors: someone becomes a leader, because he is appointed by the top, (4) Election your acceptance / acceptance concept is your leader and we will obey your instructions.[9]

In leadership, a leader certainly has characteristics. To understand more about the characteristics of leaders, George $\mathrm{R}$ Terry argues that at least the leader must have eight characteristics such as the following: (1) Energy: has mental and physical strength, (2) emotional stability: a leader must not be prejudiced bad to his subordinates, he is not quick to anger and believe in himself must be big enough, (3) Human relationship: having knowledge of human relations, (4) Personal motivation: the desire to be a leader must be large and can motivate themselves, (5) Communication skills: have the ability to communicate, (6) Teaching skills: have the skills to teach and develop subordinates, (7) Social skills: have expertise in the social field, so that the trust and loyalty of subordinates is guaranteed. He must be helpful, happy if his subordinates are advanced, friendly and flexible in association, (8) Technical competent: have the skills to analyze, plan, organize, delegate authority, make decisions and be able to draft concepts.[10]

In Islam, being a leader also has several criteria. After tracing the Qur'ān and Hadis, the ulama set forth four traits that must be fulfilled by the leaders of the ummah which were concluded from the prophets, namely: (1) Ash-Shidq, namely truth and sincerity in acting, speaking, and striving to carry out their duties ( 2) Al-Amanah, or trust, which makes him maintain the best of what is given to him, both from God and from the people he leads, so as to create a sense of security for all parties, (3) Al-Fathanah, namely intelligence giving birth to the ability to face and overcome problems that arise instantly though, (4) At-Tabligh, which is the delivery of honest and responsible, or can be termed "openness".[11]

Rois as a religious leader in a region certainly has a large role and responsibility. In general, a leader has the role of Interpersonal Roles, Informational Roles, and Decisional Roles.[12] Interpersonal Roles is the role in which leaders establish good relations with people around, while informational roles are the role of the leader being someone who can be used as a reference for information so that a leader is required to have extensive knowledge, then decisional roles is the role of a leader in making decisions which is fair to all parties.

Pursuing Islamic teachings, as religious leaders, as mentioned by Dadang Ahmad, has several roles, namely as a motivator, moral guide and mediator.[13] Each leader has their own obstacles and difficulties, especially in religious leaders. Religious leaders have their own challenges in facing the times, here are some of the challenges described by Gus Dur, namely (1) The lack of local and national Islamic leaders at the same time, (2) At least Islamic leaders are religious experts and organizers, (3) religious bureaucratization, (4) Differences in political attitudes vis a vis the government, (5) Differences in activities or fields of cultivation, (6) Differences in thought orientation, (7) Intervention of information flows.[14]

\section{METHODOLOGY}

The approach used in this study is the sociological approach of religion because in this study the symptoms of the relationship between rois, religion and society are the focus of research. Then, the research subjects were selected using the purposive sampling method, where the sample units contacted were adjusted to certain criteria based on the research objectives. In this case the primary data will be the result of interviews with Rois, the Maguwoharjo villagers, the head of the KUA community section and the Head of the Public Welfare Section Maguwoharjo. While secondary data can be in the form of magazines, bulletins, publications from various organizations, study results, survey results, historical studies and others. On this occasion, secondary data was used to strengthen the discovery and complete the information that had been collected through direct interviews with the speakers.

In order to facilitate collecting the data, this study uses the method of observation, interviews and documentation. In conducting this research, it uses inductive thinking patterns, which is the method of thinking that departs from facts or special events then generalizations.[6] These following are step in analyzing the data: (1) Reviewing various data that has been collected from field notes, personal documents, official documents, then the data is read, studied and understood, (2) After reading, understanding the data collected then data reduction, which is choosing data that can be processed further by doing abstraction. Abstraction is an attempt to make a core summary, processes and statements that are maintained so that they remain in it, (3) Arrange data into units then categorize, (4) Categorize data while making coding. Coding is the process of categorizing qualitative data and also describes the implications and details of the categories, (5) Checking the 
validity of the data by data triangulation, (6) After completing the final stage of checking the validity of the data and then interpreting the data into temporary results substantive theory using certain methods.[15]

As mentioned above, to validate the data it is done by data triangulation. This can be achieved in the following ways: (1) Comparing observation data with the results of interviews, (2) Comparing what is said in public with what is said personally (for rois), (3) Comparing what people say about the situation of the research with what is said all the time (for the people of Maguwoharjo Village), (4) Compare the situation and perspective of a person with various opinions and views of people, (5) Compare the results of interviews with a valid document.

\section{RESULTS}

In this section, researchers did not directly discuss this role. This section is a clear picture of rois in society because indeed Rois does not have a standard record in writing, only in the form of oral law in the community. This section will discuss the nature of various aspects, starting from the Rois task and its challenges and rois requirements.

\section{A. The Rois task and its challenges.}

Rois has a variety tasks in his role as a religious guide to the community. However, from all respondents and from the observations, the researchers found that the main task of Rois was to take care of the procession, starting from bathing, wrapping the corpse, lead the pray, burying, praying after the funeral, praying for the death commemoration starting from 3 days, 7 days, 40 days up to 1000 days. The role of the rois that is visible to the public is seen as the main and very important thing.

The high community needs for Rois as someone who understands and able to carry out the process of taking care of the body, because not many people want to take care of the corpse even though the actual task of taking care of the corpse is the duty of fellow Muslims regardless of their position. The reason people unwilling to be involved in taking care of the bodies is because of disgust or fear. The community is very entrusting the task to take care of the corpse to Rois. Rois is the person who knows the most to take care of the corpse, also Rois is one of the most capable for it because actually he has received training from the KUA and the local village office about taking care of the corpses.

The next task that attached to the role of Rois is to lead prayers in events such as aqiqahan events, laying the first stone in the construction of houses, celebrating success in business or education, celebrating Islamic holidays, commemorating the death of someone and so forth. The essence of the activity is to send prayers to God in various backgrounds as mentioned. Every role in life has its own challenges, as Rois also faces its own challenges. The challenges concluded into two common points, namely being a rois needs 24-hour preparedness and faces the differences understanding among the community.

\section{B. Rois Conditions.}

The task carried out by a rois is certainly tough task, therefore the requirement to become a religious leader in society is certainly as difficult as that task. It is found that there are several points that must be owned by someone until the individual can be chosen as a rois. Before that, it needs to explain how the rois selection path in a village/hamlet.

Becoming a rois does not require administrative registration and selection such as hamlet elections or village headman. The selection of the rois will occur if the previous rois is no longer able to carry out his duties as rois. This happens because of death or enfeebled from illness or age, then there will be a rois election in the hamlet. Rois is based on hamlets, meaning that every single hamlet must have one rois or more. In the context of Maguwoharjo Village, one hamlet can have more than one or even up to five rois, due to the large area of this village or it separated by ringroad.

The procedure for choosing a rois is more or less like the following step. The selection of rois is usually held at the village hall led by a village headman and attended by several community leaders such as the RT leader or RW chairman and representatives from several other residents. The discussion held until a decision was made as the next replacement rois. It is certanty that the next rois substitute is someone who has qualified as rois. Although there is actually no standard and written requirement for being a rois, at least one rois must have the following: Extensive religious insight, Practicing the teachings of Islam in daily life so he can be an example for others, Can read the Qur'an correctly, It's old, in the sense of having experience in religious matters, Approved by the community, Willing to carry out duties as a rois in the community.

The two rois tasks that have been described above are tasks that are seen and understood by society in general. However, the true task of Rois is not just to be a leader in religious rituals. According to the researcher, after various observations, interviews with the people concerned, and reflecting on the meaning behind it all, the researchers found that Rois' task was not just to pray for people who have a purpose, but more than that. Rois's real task is to guide the community back to the teachings of Islam. This is understood by Rois as a whole. Because if the existence of the rois is only to pray for people, then there is no need to rois, because anyone can also become a prayer.

\section{DISCUSSION}

It appears that the core of Rois' role in society is not just a prayer reader in religious rituals. Rois gives influence to the community so that the community practices Islamic teachings properly and correctly. So, it is true that the Rois task is a difficult task, because the role is trying to change people's behavior in terms of religion. Some rois also stated that the Rois task was heavy and could be classified as a sabilillah task because being a rois did not achieve a salary, it is a voluntary task given by the community. Rois' role further emphasizes the changes of people's behavior in the field of worship. The tasks of leading prayers in religious rituals are merely the elaboration of the core tasks of Rois in guiding the community regarding religious issues. To point out, the core task is inviting Muslims to carry out orders and stay away from Allah's prohibitions as the teachings of Islam.

Rois tasks in the community are said to be voluntary, but not entirely voluntary. Every time rois do a prayer on an occasion, a rois is given an envelope containing at least fifty thousand rupiah, depending on the person who has the right to give money because it could be more than that. Rationally, of 
course this is done to appreciate the rois who came and prayed. In Javanese customs giving money to the rois is called the key to prayer, so if you don't give an envelope, people who have the intention are not sure that they have been prayed for. Besides that, if rois rejects the envelope, those who have the intention will feel offended and assume that the rois is arrogant because they reject the envelope.

Community of rois is a place for rois to share experiences and exchange ideas about religious issues in their area. Maguwoharjo village itself does not have this association, the existence of this community is at the Depok Sub-district level, another village. Rois, who has been active in his area for a long time, fully understands that his duties and role is as a religious leader or rois. They have strategies or steps that are specifically taken to to change society into a better Moslem. Although the strategies chosen by Rois vary, depending on the character of the rois itself, all of these strategies are the best way to be able to change the behavior and mindset of the community.

At least there are three of the most influential ways that can be done by Rois to build an Islamic society that are giving examples and being role models, giving an introduction before performing religious rituals and making a personal approach to the community.

\section{A. Giving examples and being role models.}

The first thing that is most suitable for influencing society is by giving an example. If its wanted to have people who are diligent in praying in congregation in the mosque, then give an example to the community in advance that Rois does this. The closest person is someone who can influence the formation of one's character. This is easier to do because Rois interacts directly with the community itself. In addition, Rois is a community figure, where daily life is highlighted and imitated by the community. Moreover, based on the observations of the researchers, a rois was chosen because his daily habits reflected the personalities of Moslems who obeyed the values of religion. The most visible thing, as previously explained that prayer to the mosque is the simplest thing that can make the rois a model. Therefore, giving an example or being an example in religious matters is the best strategy for Rois to influence the community so that it can change its character so that an Islamic society is created.

\section{B. Giving an introduction before performing religious rituals.}

In his activities as a leader in the field of religion, the experienced Rois also made religious rituals a medium of propaganda. Da'wah media chosen by Rois is the best way to be able to touch the community, especially the people who are still thick with Javanese customs. The introduction given before the ritual begins in the form of lectures or tausiyah for approximately 5 to 10 minutes. With that little time, Rois can give meaningful and direct lectures at its core. The contents of the lecture vary, depending on the current moment, for example the warning of the Prophet's birthday, Rois explains what the purpose of the activity is. The following are some examples of the contents of the lecture before the religious ritual, namely how to educate children, how about sustainable education, remind the provision for death, about the purpose of life, about the household so that the worship is istiqomah, regarding warnings to thicken faith, purpose of tahlilan, how Islam views these activities and so forth.

\section{Making a personal approach to the community.}

Another step taken to gradually change the character of the community is to approach the community personally. All this has been done by Rois, because with the rois coming and praying for religious ritual activities is a way to be able to approach the community. Because if it's close, then it can be known what the community really wants. That way the rois can adjust to direct the community as it is. If necessary, Rois approached the people personally, directed and advised head to head. This can be done anywhere, even at the rois house. According to observations of the research, Rois, who is very close to the community, is often visited by residents to ask for direction on the problems their facing. Individuals who came to the Rois residence shared the problems they were facing and asked for advice on how to act on the problem. The problems commonly asked are about religious matters.

\section{CONCLUSION}

It can be conclude from this research that role of the rois is not only leading the religious rituals such taking care of corpse but the core of the role is building the islamic character of the society where the rois live in. Rois's role is to restore people's understanding of religious rituals that have been wrong so far.

\section{REFERENCES}

[1] Khadziq, 2009, Islam and Local Culture: Learning to Understand the Reality of Religion in Society, Yogyakarta: Teras, pg. 113-114.

[2] Syarifuddin Jurdi, 2008, Islamic Sociology Elaborates on the Social Thought of Ibn Khaldun, Yogyakarta: Academics of UIN Sunan Kalijaga Yogyakarta, pg. 186

[3] This is the hope of the community that was obtained by the researcher through the initial observation of the research and according to the Head of the Public Welfare Section Maguwoharjo, because there is indeed no written law about this rois in the community.

[4] Ministry of Religion, 2015, Minutes of Prayer, Sleman: Islamic Religious Affairs Office of the Ministry of Religion.

[5] Interview reports with Bambang Hartoyo, one of residents in Maguwoharjo.

[6] Ahmad Warson Munawwir, 1984, Al-Munawwir Arabic-Indonesian Dictionary, Yogyakarta: Procurement Unit of Krapyak Islamic Boarding School Religious Books, pg. 493.

[7] KH. Adib Bisri, 1999, Dictionary of Al Bisri: Indonesian-Arabic Arabic-Indonesian, Surabaya: Pustaka Progressif, pg. 228.

[8] Language Center Dictionary Compilation Team, 2002, Indonesia Dictionary, vol.3, Jakarta: Balai Pustaka, pg. 686.

[9] Irham Fahmi, 2013, Management of Theory and Application Leadership, vol.2, Bandung: Alfabeta, pg. 31.

[10] Brantas, 2009, Fundamentals of management, Bandung: Alfabeta, pg. 136-137.

[11] Veithzal Rivai and Arviyan Arifin, 2009, ISLAMIC LEADERSHIP: Building Superleadership Through Spiritual Intelligence, Jakarta: Bumi Aksara, pg. 113.

[12] Armanu Thoyib, 2009, "Relationship between Leadership, Culture, Strategy and Performance: Conceptual Approach", Journal of Management and Entrepreneurship, vol.11, no.2, pg. 60-73.

[13] Dadang Kahmad, 2002, Sociology of Religion, Bandung: Remaja Rosdakarya, pg. 138.

[14] Jalaluddin Rakhmat, "Questioning the Origins of Islamic Leaders" hlm.27-28.

[15] Sutrisno Hadi, 1987, Research Methodology 2, Yogyakarta: Andi Offset, pg. 42. 